\title{
Photosensitizer LUZ 11
}

National Cancer Institute

\section{Source}

National Cancer Institute. Photosensitizer LUZ 11. NCI Thesaurus. Code C114382.

\begin{abstract}
A bacteriochlorin-based photosensitizer, with antineoplastic activity upon photodynamic therapy (PDT). Following intravenous administration, the photosensitizer LUZ 11 preferentially accumulates in hyperproliferative tissues, such as tumors. Local application of laser light at the tumor site results in the absorption of light by this agent and a photodynamic reaction between LUZ 11 and oxygen. This results in the production of reactive oxygen species (ROS), which includes sing let oxygen molecules, the superoxide ion, and other cytotoxic free radicals. The formation of ROS induces free radicalmediated DNA damage and cell death.
\end{abstract}

